\title{
Sustainable water management analysis using nested adaptive systems
}

\author{
B. Jenkins \\ Waterways Centre for Freshwater Management, \\ University of Canterbury and Lincoln University, New Zealand
}

\begin{abstract}
The paper uses the approach of "nested adaptive systems" to establish an operational definition of sustainable management of three significant issues in the Waimakariri catchment of the South Island of New Zealand: availability of water for irrigation, public water supply for Christchurch urban area, and gravel extraction from the bed of the Waimakariri River. Different spatial scales were determined for sustainability analysis. Using the adaptive cycle of exploitation, accumulation, disturbance/release and reorganisation, critical variables for maintaining the resilience of each system and the thresholds for management interventions to achieve sustainable systems were identified. Also crucial for sustainability was the maintenance of the linkages between the different spatial scales.

Keywords: critical variables for resilience, nested spatial scales, adaptive cycle, system vulnerability, sustainable irrigation, sustainable public water supply, sustainable gravel extraction.
\end{abstract}

\section{Introduction}

The Waimakariri catchment $\left(3654 \mathrm{~km}^{2}\right)$ is in the central east coast of the South Island of New Zealand. This paper addresses three sustainability issues associated with the catchment:

- the management of the Waimakariri irrigation scheme

- the public water supply for Christchurch urban area, and

- the extraction of gravel from the bed of the lower reaches of the Waimakariri River. 
The framework of nested adaptive systems is used for sustainability analysis. This is based on the four phases of the adaptive cycle (Gunderson and Holling [1]):

- exploitation: the use of resources

- accumulation: the build-up of material or energy in the system

- disturbance/release: a disturbance to the system that can cause release of material or energy and change the structure and function of the system

- reorganisation: the restructuring of the system after disturbance.

System response can be a recovery of the original system (i.e. sustainable) or a shift to an alternative state (i.e. unsustainable). Systems can be nested: they can operate at different spatial and time scales which are linked. This provides an operational basis for defining sustainability. Sustainability is the maintenance of the structure, function and relationships in the adaptive cycles across different time and geographical scales. A key property for sustainability is "resilience" - the capacity of a system to absorb disturbance and still retain its basic function and structure. Linked adaptive cycles are identified for the three Waimakariri catchment sustainability issues. For sustainability analysis priority needs to be given to the critical variables that create the greatest vulnerability to an adaptive cycle and to the linkages between the different spatial and temporal scales. Management interventions to ensure that critical variables are within resilience thresholds and that the linkages between different scales are maintained are the essence of an operational basis for sustainability.

\section{Management of the Waimakariri irrigation scheme}

There are three geographical scales to be considered for the sustainable management of the Waimakariri irrigation scheme:

- the Waimakariri catchment as the source of water for the irrigation scheme

- the irrigation scheme as the source of water for the farmer

- the individual farm where the irrigation water is applied.

For each of these levels the adaptive cycle of exploitation/accumulation/ disturbance-release/reorganisation can be described.

\subsection{Adaptive cycle for the Waimakariri catchment for irrigation takes}

The key components of the adaptive cycle for the Waimakariri River catchment in relation the management of the Waimakariri irrigation scheme are:

- exploitation: the rainfall that falls on the catchment that generates runoff

- accumulation: the accumulation of runoff that generates river flow

- disturbance-release: the volume of water that is extracted from the river for irrigation

- reorganisation: the adequacy of the remaining flow to sustain the river ecology and uses downstream of the irrigation take. 
The sustainability threat for the river is the adequacy of the flow downstream of the irrigation take. If this flow is inadequate to maintain river ecology and instream uses then the river will have been degraded through the disturbance of water extracted for irrigation.

The critical variables for river management are the flow requirements for the uses downstream of the irrigation take and the restrictions placed on the amount that can be extracted at particular river flows for irrigation. These include the low flows when aquatic systems are likely to be under the greatest stress, smaller floods and freshes to mobilise sediment and remove periphyton, and large floods to maintain the river's braided character (Jowett and Biggs [2]). The main flow statistics for the Waimakariri River are set out in Table 1.

Table 1: Flow statistics for Waimakariri River.

\begin{tabular}{|c|c|l|}
\hline Flow Statistic & Value & \multicolumn{1}{c|}{ Comments } \\
\hline Median & $90 \mathrm{~m}^{3} / \mathrm{s}$ & Flow that is equaled or exceeded half the time \\
\hline $\begin{array}{c}\text { Mean Annual } \\
\text { Flood }\end{array}$ & $1,495 \mathrm{~m}^{3} / \mathrm{s}$ & $\begin{array}{l}\text { Average of the highest instantaneous flow } \\
\text { measurement from each year }\end{array}$ \\
\hline 7DMALF & $40.2 \mathrm{~m}^{3} / \mathrm{s}$ & $\begin{array}{l}7 \text { day annual flow is the lowest flow at a } \\
\text { given site over 7 consecutive days in a year; } \\
\text { annual values are averaged to give 7DMALF }\end{array}$ \\
\hline FRE 3 & 15 per year & $\begin{array}{l}\text { Number of occurrences of 3 times median } \\
\text { flow }\left(270 \mathrm{~m}^{3} / \mathrm{s}\right)\end{array}$ \\
\hline
\end{tabular}

The allocation regime has been defined in the Waimakariri Regional Plan (Environment Canterbury [3]). The key parameters are shown in Table 2.

Table 2: Waimakariri River allocation regime.

\begin{tabular}{|c|c|c|l|}
\hline $\begin{array}{c}\text { Allocation } \\
\text { Block }\end{array}$ & $\begin{array}{c}\text { Allocation } \\
\text { Limit }\left(\mathrm{m}^{3} / \mathrm{s}\right)\end{array}$ & $\begin{array}{c}\text { Minimum } \\
\text { Flow at } \\
\text { Otarama } \\
\left(\mathrm{m}^{3} / \mathrm{s}\right)\end{array}$ & \multicolumn{1}{|c|}{ Notes } \\
\hline $\begin{array}{c}\text { AA } \\
\text { permits }\end{array}$ & 5 & - & $\begin{array}{l}\text { Stock and drinking water: can be taken at } \\
\text { any river flow }\end{array}$ \\
\hline A permits & 17 & 46 & $\begin{array}{l}\text { Need to cease takes during a fresh that } \\
\text { occurs after a period of 21 days of flow } \\
\text { below A permit minimum flow; } \\
\text { includes } 10.5 \mathrm{~m}^{3} / \mathrm{s} \text { for Waimakariri } \\
\text { irrigation }\end{array}$ \\
\hline B permits & 27 & 68 & $\begin{array}{l}1: 1 \text { flow sharing; Need to cease takes } \\
\text { during a fresh that occurs after a period of } \\
21 \text { days of flow below A permit minimum } \\
\text { flow; } \\
\text { includes } 25 \mathrm{~m}^{3} / \mathrm{s} \text { for future irrigation }\end{array}$ \\
\hline
\end{tabular}


The allocation regime can be compared with the default values for the proposed National Environmental Standard for ecological flows (Ministry for the Environment [4]). The default value for minimum flow for rivers with mean flows greater than $5 \mathrm{~m}^{3} / \mathrm{s}$ is $80 \%$ of MALF or $32.2 \mathrm{~m}^{3} / \mathrm{s}$ for the Waimakariri River compared to the minimum flow in the allocation regime of $46 \mathrm{~m}^{3} / \mathrm{s}$. The default value for the allocation limit is $50 \%$ of MALF or $20.1 \mathrm{~m}^{3} / \mathrm{s}$ for the Waimakariri River compared to the combined AA and A permits of $22 \mathrm{~m}^{3} / \mathrm{s}$ in the allocation regime.

For the B block allocation, the critical issues are the need to have flows in the range 55-96 $\mathrm{m}^{3} / \mathrm{s}$ during September to December for riverbed nesting bird breeding and to have flow in the range $60-100 \mathrm{~m}^{3} / \mathrm{s}$ during December to April for salmon angling. If flows were sufficient for these activities then there would be sufficient flow for salmon passage, kayaks and jet boats (Duncan [5]). Abstractions are likely to reduce the magnitude and frequency of small freshes capable of flushing sediment and periphyton. In order to mitigate this effect consent conditions are required to maintain the frequency of flows greater than 80 $\mathrm{m}^{3} / \mathrm{s}$ and preferably greater than $130 \mathrm{~m}^{3} / \mathrm{s}$ after a period of low flows of sufficient duration which potentially allow the growth of periphyton to nuisance levels (Duncan [5]). These issues are addressed through 1:1 flow sharing and the need to cease takes during a fresh after periods of 21 days below the A permit minimum flow.

In terms of extraction the current major take is the Waimakariri irrigation scheme (A permit for $10.5 \mathrm{~m}^{3} / \mathrm{s}$ ).

\subsection{Adaptive cycle for Waimakariri irrigation scheme}

At the next geographical scale is the irrigation scheme. The adaptive cycle for the irrigation scheme can be defined as follows:

- exploitation: irrigation take subject to river flow restriction

- accumulation: water for distribution from irrigation canals or from storage

- disturbance-release: release of irrigation water to farmers

- reorganisation: further irrigation supply from river or storage

As an A permit scheme, water cannot be taken from the Waimakariri River below the minimum flow of $46 \mathrm{~m}^{3} / \mathrm{s}$. Above $68 \mathrm{~m}^{3} / \mathrm{s}$ the full allocation of 10.5 $\mathrm{m}^{3} / \mathrm{s}$ can be taken. Between 46 and $68 \mathrm{~m}^{3} / \mathrm{s}$ a proportion of the full allocation can be taken.

The flow in the Waimakariri River is highly variable and is typically low in February to April of the irrigation season. At the present time the Waimakariri irrigation scheme is fully reliable for only one year in 42 based on simulations using past flow records. One way of increasing the reliability of supply is to provide scheme storage. Consent has recently been granted for an 8.2 million $\mathrm{m}^{3}$ storage which provides for nine days of storage for supplying the entire scheme. If surplus consented water is used to refill the storage throughout the irrigation season the scheme would be fully reliable for 23 of the past 42 years. 


\subsection{Adaptive cycle for on-farm irrigation}

The third geographical scale in this nested system is the farm which uses irrigation water from the scheme. The adaptive cycle for on-farm irrigation can be described as:

- exploitation: irrigation to supplement rainfall

- accumulation: soil moisture levels on irrigated farmland

- disturbance-release: evapotranspiration from the soil

- reorganisation: maintain soil moisture in the $50-80 \%$ range for optimum production.

The vulnerability for the irrigating farmer is from lost production from suboptimal soil moisture conditions. Waimakariri irrigation scheme farmers lost an estimated $\$ 30$ million of production in the dry summer of 2013 because of the inability to irrigate. There is also a vulnerability to the environment from excessive irrigation saturating the soil resulting in leakage to groundwater and contamination of groundwater quality especially by nitrates.

Analysis shows the need for irrigation because the weekly potential evapotranspiration exceeds rainfall most of the time (Duncan et al. [6]). Effective irrigation involves irrigation application rates to compensate for the exceedance of potential evapotranspiration rates over rainfall.

Water availability for irrigation was constrained by low flows in the Waimakariri River, particularly in the later part of the irrigation season. This was also a time of lower rainfall. This meant that for farmers reliant on scheme distribution of water, there was not irrigation water available so soil moisture levels declined. Farmers with on-farm storage were able to continue irrigating. Onfarm storage also gave farmers greater flexibility to match irrigation application with soil moisture deficit.

\subsection{Nested adaptive cycles for irrigation}

It is possible to combine the adaptive cycles from the three different geographical cycles into a nested system. The link between the catchment scale and the irrigation scheme is the irrigation extraction from the disturbance-release phase of the catchment cycle as an input to the reorganisation phase of the irrigation scheme cycle. The link from the irrigation scheme cycle is the release to the farm for the irrigation scheme distribution system into the reorganisation phase of the on-farm irrigation system.

\section{Public water supply for Christchurch urban area}

There are three geographical scales that are relevant to the use of groundwater for the public water supply for Christchurch urban area:

- the Waimakariri catchment as the main source of recharge to groundwater

- the groundwater system and the groundwater - surface water interactions

- the groundwater extraction for public water supply and its implications. 
Each geographical scale can be described as an adaptive cycle in relation to sustainable management of groundwater with respect to public water supply for Christchurch. The three levels can then be integrated as a nested adaptive system.

\subsection{Waimakariri catchment as a source of recharge to groundwater}

The Waimakariri catchment, as with other alpine river catchments in the region, has a strong precipitation gradient from the headwaters to the mouth. At the headwaters the precipitation ranges from 2,000 to $5,000 \mathrm{~mm}$, in the foothills the range is from 1,000 to $2,000 \mathrm{~mm}$, and on the plains it is less than $1,000 \mathrm{~mm}$.

Thorpe [7] describes the geological setting of the Canterbury Plains which defines the groundwater system in the Waimakariri catchment. The Canterbury Plains were built up from coalescing alluvial fans of gravel originating in the Southern Alps. In the interglacial periods when sea level rose, marine silts and clays were deposited over gravels on the coastal margins. The final result is for an unconfined aquifer on the plains while near the coast is a sequence of gravel aquifers separated by fine-grained marine deposits that form confining layers so that much of the coastal city of Christchurch sits on at least four aquifers.

The Waimakariri River is incised across the upper plains and does not lose flow to groundwater. However, in the lower plains surface water seeps from the gravel river bed recharging the unconfined aquifers of the Canterbury Plains. In areas of the plains away from the river the recharge to groundwater is from excess rain infiltrating through the soil.

The groundwater recharge from the Waimakariri River can be described as an adaptive cycle:

- exploitation: the rainfall that falls in the catchment that generates runoff

- accumulation: the accumulation of runoff that generates river flow

- disturbance-release; the seepage of surface water to groundwater

- reorganisation: the reduced river flow downstream of the reach subject to flow loss.

The vulnerability for groundwater recharge is the maintenance of flow in the Waimakariri River. The critical variable is the seepage rate from the river to groundwater.

\subsection{The groundwater - surface water interactions}

White et al. [8] have undertaken an assessment of the interaction between groundwater and surface water in the Waimakariri River. Daily groundwater outflow from the Waimakariri River bed to the aquifer (Springston Formation) was estimated using water budgets. For the overall reach on the Canterbury Plains, the groundwater outflow to the Springston Formation gravels beside the river was estimated to be $11.7 \mathrm{~m}^{3} / \mathrm{s}$ for average river flows $\left(120 \mathrm{~m}^{3} / \mathrm{s}\right)$. There is also a net movement from groundwater (i.e. groundwater from the gravel river bed and the Springston Formation) of $1.5 \mathrm{~m}^{3} / \mathrm{s}$ back to the river near the coast.

Analysis of river flow and outflow to groundwater shows a relationship with high flows. For example, daily outflow to groundwater is greater than $15 \mathrm{~m}^{3} / \mathrm{s}$ 
when the river flow is greater than $200 \mathrm{~m}^{3} / \mathrm{s}$. However below river flows of 120 $\mathrm{m}^{3} / \mathrm{s}$ groundwater outflow is relatively uniform. Analysis of taking full irrigation takes indicated a reduction in groundwater outflow of $0.2 \mathrm{~m}^{3} / \mathrm{s}$ (White et al. [8]).

In addition to the seepage from the Waimakariri River, there is also inflow to the aquifers from rainfall recharge over the area of the confined aquifer. About $30 \%$ of rainfall infiltrates to groundwater.

The recharge to the unconfined aquifer can be described as an adaptive cycle:

- exploitation: seepage from the Waimakariri River and rainfall infiltration entering groundwater

- accumulation: increased aquifer inflows from the river seepage and rainfall infiltration

- disturbance-release: aquifer recharge which increases groundwater levels

- reorganisation: increased aquifer flow in the unconfined aquifer.

The vulnerability of the recharge to the unconfined aquifer is from the amount of seepage from the river and the amount of rainfall over the unconfined aquifer. These are the critical variables. There is also a feedback loop for groundwater surface water interactions. Further downstream, heightened groundwater levels can lead to return flow from groundwater to the Waimakariri River.

\subsection{Groundwater extraction for public water supply}

Groundwater is the source of drinking water for the urban area of Christchurch. Current extraction is about 47 million $\mathrm{m}^{3}$ per year (approximately $1.7 \mathrm{~m}^{3} / \mathrm{s}$ ). It is a high quality supply as the majority of the groundwater flow comes from the Waimakariri River. It does not require treatment to meet drinking water quality standards. It is under artesian pressure which provides protection from contaminant leakage from land use activities.

In the Christchurch - West Melton groundwater zone there is also extraction for agriculture, horticulture, industry as well as commercial and other activities. Groundwater provides the baseflow for spring-fed lowland streams such as the Avon/Otakaro and Heathcote Rivers.

Current extraction for Christchurch public water supply represents about $12 \%$ of the estimated outflow of the aquifers (about 400 million $\mathrm{m}^{3}$ per year). However consented volume for public supply is 86 million $\mathrm{m}^{3}$ per year $(22 \%$ of estimated outflow).

Groundwater extraction lowers groundwater levels and the upward artesian pressure in the aquifers. This can lead to reduced baseflow in lowland streams from lowered groundwater levels, increased risk of contamination from contaminant leakage from land use activities, and, if the groundwater levels fall below sea level, increased risk of saltwater intrusion.

This can be represented as an adaptive cycle as follows:

- exploitation: abstraction of groundwater

- accumulation: decline in groundwater level and artesian pressure

- disturbance-release: reduced flows in lowland streams and increased risk of contamination from land use and saltwater intrusion 
- reorganisation: maintenance of adequate recharge.

The sustainability risks in relation to groundwater extraction for public water supply for Christchurch are the maintenance of baseflows in lowland streams and the maintenance of quality as a drinking water supply. There is also the issue of further allocations to other uses affecting the allocation limit to public water supply. Critical variables include the demand for drinking water, groundwater quality with respect to drinking water standards, groundwater levels and pressures, baseflow in lowland streams, and allocation to other uses.

\subsection{Nested adaptive cycles for Christchurch water supply}

These different geographical scales can be linked as nested adaptive cycles. Seepage to groundwater is the link between the catchment scale and the unconfined aquifer. The link is from the disturbance-release phase of the catchment adaptive cycle to the exploitation phase of adaptive cycle for the unconfined aquifer.

The aquifer inflow is the link between the unconfined aquifer adaptive cycle and the adaptive cycle for groundwater extraction for public water supply. The link is from the reorganisation phase of the unconfined aquifer adaptive cycle to the reorganisation phase of the adaptive cycle for public water supply.

\section{Extraction of gravel from the bed of the Waimakariri River}

Three geographical areas are relevant to considering the gravel extraction for the bed of the Waimakariri River and its sustainable management:

- the Waimakariri catchment as the source of gravel

- the river reach from which gravel is extracted

- the coastal zone around the mouth of the Waimakariri River.

An adaptive cycle can be defined for each of these geographical areas.

\subsection{Adaptive cycle for the Waimakariri catchment for gravel extraction}

Sediment yield for a catchment largely depends on rainfall and geology. The Waimakariri catchment with its high rainfall in the upper catchment in the Southern Alps and greywacke rocks (a slightly metamorphosed sandstone susceptible to water erosion) has a relatively high suspended sediment yield of 989 $\mathrm{t} / \mathrm{km}^{2} / \mathrm{a}$ (Hicks [9]).

Sediment is transported by a river when the entrainment velocity threshold is exceeded for the grain size of the sediment with finer material held in suspension (suspended sediment) and coarser sand and gravels moving along the river bed (bedload transport) (Hicks [9]). The Waimakariri River has an estimated suspended sediment load of 3.1 Mt/a and a bedload of approximately $260,000 \mathrm{~m}^{3} / \mathrm{a}$ (Hudson [10]). The gravel bed in the river finishes $2.5 \mathrm{~km}$ upstream of the river mouth indicating that gravel is not transported to the coast. 
The high sediment load creates the braided character of the Waimakariri River. Aggradation of sediment in the river bed reduces the channel capacity which increases flooding risk and can eventually lead to overflows creating new river channels.

This sequence of processes can be described as an adaptive cycle:

- exploitation: the erosion in the catchment and riverbed that generates sediment in the river

- accumulation: the accumulation of sediment in the river bed

- disturbance-release: the movement of sediment when the river reaches threshold velocity for suspended sediment and bedload transport

- reorganisation: sediment removal from the bed to maintain channel capacity for the river flow.

The vulnerability of the existing river channel is the aggradation of the river bed which eventually leads to overflows forming a new channel. The critical variables for the processes are the sediment yield for the catchment, the suspended sediment and bedload transported by the river, and the rate of aggradation in the riverbed.

\subsection{Adaptive cycle for river reach where gravel is extracted}

Gravel extraction occurs from the lower reaches of the Waimakariri River. The extraction rates over the last 15 years have been between 300,000 and 700,000 $\mathrm{m}^{3} / \mathrm{a}$ (Measures [11]). This extraction rate exceeds the bedload transport rate which has led to a $1 \mathrm{~m}$ bed level reduction between 1985 and 2008. Modelling of sediment transport predicts that if no extraction had taken place that bed levels would be over $2.5 \mathrm{~m}$ higher in some reaches (Measures [11]).

Gravel extraction can therefore help maintain the floodway capacity of rivers like the Waimakariri River. However excessive gravel extraction can pose a threat in relation to the undermining of flood protection and erosion control works as well as bridge abutments. The sustainable supply of gravel from the Waimakariri River has been assessed to be $250,000 \mathrm{~m}^{3} / \mathrm{a}$ (Environment Canterbury [12]). Recent bed level investigations indicate that some of the historical gravel extraction consents have minimum bed levels that are below the currently recommended bed levels (Environment Canterbury [13]).

In addition to the direct effect on bed levels, the lowered bed levels from gravel extraction can affect the gravel transport rates for different reaches of the river. Modelling indicates that extraction has resulted in an increase (up to $60,000 \mathrm{~m}^{3} / \mathrm{a}$ ) in the excavated area and a decrease downstream of the excavated area. Furthermore the location of increased deposition corresponds to the reach where the greatest gravel extraction has taken place (Measures [11]).

In relation to reorganisation after gravel abstraction the river adjusts to the new bed levels. After a year there is a decline in bed levels within about $1 \mathrm{~km}$ of the excavated area. After 20 years a $0.5 \mathrm{~m}$ excavation has reduced to 0.1 to $0.2 \mathrm{~m}$ in depth and there reduced bed levels within $4 \mathrm{~km}$ upstream and downstream of the excavated area. 
The adaptive cycle for these processes can be set out as follows:

- exploitation: gravel extraction from the river bed

- accumulation: reduction in river bed levels

- disturbance-release: the effect of lowered bed levels on sediment transport rates

- reorganisation: bed level adjustment with reductions in level upstream and downstream, and infilling of the excavated area.

The vulnerability for gravel extraction is the lowering of bed levels to the point where engineering works are undermined. Critical variables in the cycle are the bedload transport rate, the gravel extraction rate and bed levels.

\subsection{Adaptive cycle for the coastal zone near the Waimakariri River mouth}

River sediment is one of the major sources of sediment with respect to the sediment budgets for coastal systems. Excavation of gravel from a river bed forms pits within the channel profile which can trap much of the incoming bedload sediment preventing it or slowing it from reaching the coastline.

The Waimakariri River is the largest contributor of sediment to Pegasus Bay and represents about $77 \%$ of the sediment supplied to Pegasus Bay. Estimates of suspended sediment load vary from $2.78 \mathrm{Mt} / \mathrm{a}$ to $5.36 \mathrm{Mt} / \mathrm{a}$. If the beach sand fraction is between 20 and $40 \%$, then this gives a beach sand load of between 0.6 and 2.1 Mt/a (Hicks [14]).

With respect to gravel extraction, the river is essentially a closed system with gravel deposition ceasing about $2.5 \mathrm{~km}$ from the coast. This means there should be little or no effect of river gravel extraction on the coast. The sandy beaches nourished by the Waimakariri River are accretionary which indicates the sand fraction reaching the coast is sufficient to maintain the stability of the southern Pegasus Bay shoreline (Environment Canterbury [12]). Modelling by Hicks [15] predicts an advancement of the shoreline by $40 \mathrm{~m}$ over the next 50 years.

Any changes to the sediment contribution from the Waimakariri River would have significant implications for the coastal sediment budget. Modelling by Hicks [15] of a $50 \%$ reduction in the supply of river sand over 50 years predicts shoreline retreat of $80 \mathrm{~m}$ inland and extending over $8 \mathrm{~km}$ around the river mouth.

This interaction between gravel extraction and coastal processes can be expressed as an adaptive cycle:

- exploitation: sediment discharge to the coast

- accumulation: accumulation of sediment as beach deposits

- disturbance-release: coastal erosion leads to loss of sediment

- reorganisation: sediment supply maintained so that coastal sediment budget is maintained.

The vulnerability of the coastal system is in relation to the ongoing sediment supply from the river but not the gravel supply. Critical variables are the sediment supply to the coast and coastal erosion rates. 


\subsection{Nested adaptive cycles for gravel extraction}

The linkage between the catchment level and the extraction reach is the river transport rate, in particular, the bedload transport of gravel. The linkage between the extraction reach and the coastal processes is the sediment supply to the coast and in this instance the sand supply.

\section{Discussion and conclusions}

The nested adaptive systems approach provides a framework for the definition of sustainability limits. The approach considers adaptive cycles (i.e. exploitation/ accumulation/disturbance-release/reorganisation) at multiple spatial scales. The approach identifies critical variables that can cause the adaptive cycle to fail and identifies the linkages between different spatial scales that need to be maintained. The critical variables and the linkages that determine the limits will depend on the socio-ecological system under consideration. A systems approach with multiple spatial scales leads to different management interventions from linear, problemfocused approaches used in the past.

In drought-prone Canterbury, irrigation is valuable in maintaining agricultural production. Following an analysis of future water demand and potential supply (Morgan et al. [16]), the way forward was seen as further extraction or storage on rivers like the Waimakariri with their headwaters in the Southern Alps. These alpine rivers account for $88 \%$ of annual flow in the region. As shown in the nested adaptive system analysis for irrigation, setting environmental flows in the river (catchment scale), scheme storage for reliability of supply (irrigation scheme scale), and on-farm storage and soil moisture demand irrigation (on-farm scale) were critical. There has been a major debate in relation to the allowable irrigation extraction from the Waimakariri River between out-of-river users (irrigators) and in-river users (fishermen, kayakers) on how much flow needs to remain in the river. Taking a nested adaptive systems approach has broadened the debate to consider the provisions of irrigation scheme storage and on-farm storage (Canterbury Water [17]).

In relation to Christchurch's groundwater supply the initial controls were based on drawdown interference effects and low groundwater level effects. To address concerns about drinking water availability for public water supply, restrictions were placed on abstraction from private bores based on groundwater level. Progressive restrictions were defined in a series of steps as groundwater levels declined (Pattle Delamore Partners and Canterbury Regional Council [18]). Evidence of the drying of the headwaters of groundwater-fed streams (Daly [19]) indicated that a management system based on groundwater interference was insufficient. The nested adaptive systems analysis for public water supply from an aquifer primarily fed from river leakage, indicated the critical variables were maintenance of river flow (catchment scale), seepage from the river (groundwater - surface water interaction scale), and, maintenance of groundwater-fed streams and maintenance of aquifer pressure to prevent contaminant leakage (groundwater extraction scale). 
For gravel extraction, the initial management strategy was to encourage extraction as a key method of increasing and maintaining flood capacity because of the high rate of sediment accumulation in Canterbury rivers. However with increasing demand, increased gravel abstraction near convenient access points in rivers, led to concerns about river bank stability and the need for a more comprehensive approach for sustainable gravel extraction in order to manage the cumulative effects of multiple extractors (Environment Canterbury [20]). A review was undertaken to quantify the scale of the regional gravel resource and relate sustainable supply to regional demand. The review led to a change in the way gravel should be managed. The review showed increasing demand while the sustainable supply of river gravel was relatively small, highlighting the need to plan for land-based extraction (Environment Canterbury [21]). In the nested adaptive system analysis for gravel extraction from the Waimakariri River, river avulsion from aggradation (catchment scale), maintaining bed levels to avoid infrastructure damage (gravel extraction reach scale), and maintaining sand supply, rather than gravel supply, to the coast for shoreline stability (coastal zone scale) were the critical variables.

While the nested adaptive system analysis indicates that gravel extraction from the Waimakariri River is not a sustainability issue in relation to coastal processes, there are other segments of the Canterbury coastline where this is a concern. Amberley Beach on the North Canterbury coast is between two rivers, the Waipara and the Kowai, which do supply gravel to the coast. Following over a century of accretion, Amberley Beach has suffered retreat since the 1980s (Geotech Consulting [22]). Nourishment works added 10,000 $\mathrm{m}^{3}$ of gravel in 2004 and a further $6,000 \mathrm{~m}^{3}$ in 2007 . Influence on coastal processes is now a sustainability management criterion for gravel extraction (Environment Canterbury [21]).

The analysis identified that there are some sustainability issues, such as the reliability of supply for the Waimakariri irrigation scheme and the bed levels in the river due to gravel abstraction. It also identified issues that are not a current problem, such as the seepage from the Waimakariri River to the aquifer, and the sediment supply to the coast. Furthermore it highlighted some potential future problems, such as the impact of further extraction for public water supply. Some of the critical variables were beyond reasonable management influence, such as bedload transport in the river, and coastal erosion rates along the coast. However other critical variables could be influenced by management intervention to enhance sustainability, such as provision of scheme and on-farm storage to improve reliability of supply, and placing bed level restrictions on gravel extraction from the river.

The nested adaptive system approach identifies multiple failure pathways for which management interventions might be needed. It can predict in advance the issues that need to be addressed and for which limits need to be set such as the need to develop a sustainability strategy for Christchurch water supply from groundwater; this is particularly the case as the preferred means of providing additional capacity is a storage on the Waimakariri. As noted in the dredging analysis, such a storage would reduce sand supply to the coast leading to coastal erosion. 
The nested adaptive system approach contrasts with the linear problem solving approach where it was the experience of adverse consequences that led to the recognition of the need for new management approaches which could have been predicted by nested adaptive system analysis.

\section{References}

[1] Gunderson, L.H. \& Holling, C.S., Panarchy: Understanding Transformations in Human and Natural Systems. Island Press, Washington, 2002.

[2] Jowett, I. \& Biggs, B., Flow regime requirements and biological effectiveness of habitat-based minimum flow assessments for six rivers. International Journal of River Basin Management 4(3): 179-189, 2006.

[3] Environment Canterbury, Waimakariri Regional Plan, Environment Canterbury, Christchurch, 2011.

[4] Ministry for the Environment, Proposed National Environmental Standard on Ecological Flows and Water Levels, Ministry for the Environment, Wellington, 2008.

[5] Duncan, M., Waimakariri River: B/C Block allocation review, prepared for Environment Canterbury, Christchurch, 2008.

[6] Duncan, M., Srinivasan, M. S., Diettrick, J., Improved irrigation management on water metering information: 2009-10 irrigation season, NIWA Client Report: CHC 2010-091, Christchurch, 2010.

[7] Thorpe, H., The Canterbury Plains. In: Mosley, P. (ed) Waters of New Zealand, NZ Hydrological Society, Wellington, 1992.

[8] White, P., Kovacova, E., Zemansky, G., Jebbour, N. \& Moreau-Fournier, M., Groundwater - surface water interaction in the Waimakariri River, New Zealand, and groundwater outflow from the river bed, Journal of Hydrology (NZ) 51(1): 1-24, 2012.

[9] Hicks, M., Stream sediment load and organic matter. In: Harding, J. (ed) Freshwaters of New Zealand, NZ Hydrological Society and NZ Limnological Society, Wellington, 2004.

[10] Hudson, H., Waimakariri River: Status of gravel resources and management implications. Environment Canterbury, Christchurch, 2005.

[11] Measures, R., Modelling gravel transport and bed level change in the Waimakariri River, NIWA, Christchurch, 2012.

[12] Environment Canterbury, Regional Gravel Management Report, Environment Canterbury, Christchurch, 2006.

[13] Environment Canterbury, Waimakariri River Bed Level Investigation, Environment Canterbury, Christchurch, 2009.

[14] Hicks, M., Sediment budgets for the Canterbury Coast - a review, with particular reference to the importance of river sediment, NIWA, Christchurch, 1998.

[15] Hicks, M., Modelling Long-term Change of the Pegasus Bay Shoreline, NIWA, Christchurch, 1993. 
[16] Morgan, M., Bidwell, V., Bright, J., McIndoe, I. \& Robb, C., Canterbury Strategic Water Study, Lincoln Environmental, Lincoln, 2002.

[17] Canterbury Water, Canterbury Water Management Strategy Strategic Framework, Environment Canterbury, Christchurch, 2009.

[18] Pattle Delamore Partners and Canterbury Regional Council, ChristchurchWest Melton Groundwater: Existing Management Practices, Canterbury Regional Council, Christchurch, 1997.

[19] Daly, A., Christchurch Rivers Survey September 2006: Report of a survey on waterways appearance and flows, Environment Canterbury, Christchurch, 2006.

[20] Environment Canterbury, Regional Gravel Management Report, Environment Canterbury, Christchurch, 2006.

[21] Environment Canterbury, Canterbury Regional River Gravel Management Strategy, Environment Canterbury, Christchurch, 2012.

[22] Geotech Consulting, Hurunui District Engineering Lifelines Project: Natural Hazards Assessment, Environment Canterbury, Christchurch, 2000. 